Vol. 7 No. 2 Juli 2018

E-ISSN : 2502-3101 P-ISSN : 2302-528x

http://ojs.unud.ac.id/index.php/jmhu

\title{
Dugaan Praktek Monopoli Pada Sistem Pembayaran Penerimaan Negara Bukan Pajak (PNBP) Notaris Melalui Aplikasi YAP (Your All Payment)
}

\author{
Ni Putu Putrika Widhi Susmitha ${ }^{1}$
}

${ }^{1}$ Fakultas Hukum Universitas Airlangga, E-mail: putrikawidhi@yahoo.co.id

\begin{tabular}{l}
\hline Info Artikel \\
\hline Masuk: 28 Juni 2018 \\
Diterima: 18 Juli 2018 \\
Terbit: 31 Juli 2018 \\
Keywords: \\
Monopoly Practice; Payment \\
System; Your All Payment \\
Application; Non-Tax State \\
Revenue; Notary \\
10.24843/JMHU.2018.v07.i02 \\
.p7 \\
Dorresponding Author: \\
Ni Putu Putrika Widhi \\
Susmitha, E-mail: \\
putrikawidhi@yahoo.co.id \\
Satem Pembayaran Aplikasi \\
Bukan Pajak; Notaris \\
\end{tabular}

\begin{abstract}
All Notaries are required to pay Non-Tax State Revenue (PNBP) only through Your All Payment (YAP) application. The policy indicates the alleged violation of Article 17 of Law Number 5 Year 1999 concerning Anti-Monopoly and Unfair Business Competition. It is alleged that giving of privilege to one of the business actor is BNI to be the sole intermediary for payment of Non-Tax State Revenue by Notary. The purpose of this study is to examine the provisions related to monopoly and unfair business competition and its implementation in Indonesia and single payment system in the payment of PNBP online. This research uses normative legal research with statutes approach. The study shows the alleged monopolistic practice that is contradictory to Article 17 should be examined by KPPU by using Rule of reason approach. So, KPPU can maximally perform its duties considering KPPU is not law enforcement institution and sanction given is only administrative. BNI becomes the only medium for Notaries to make PNBP payments and does not need to compete with other business actors. The government should review this. It should not only be locked to one particular electronic payment system model that is on one candidate of a technically qualified bank to realize an online payment system but also should be able to accept non-electronic ones.
\end{abstract}

\footnotetext{
Abstrak

Seluruh Notaris diwajibkan melakukan pembayaran Penerimaan Negara Bukan Pajak (PNBP) hanya melalui aplikasi Your All Payment (YAP). Kebijakan tersebut mengindikasikan terjadi dugaan melanggar Pasal 17 Undang-Undang Nomor 5 tahun 1999 tentang Anti Monopoli dan Persaingan Usaha Tidak Sehat. Diduga adanya pemberian keistimewaan kepada salah satu pelaku usaha yaitu Bank BNI untuk menjadi perantara satu-satunya atas pembayaran PNBP oleh Notaris. Tujuan dari penulisan ini untuk mengkaji ketentuan terkait monopoli dan persaingan usaha tidak sehat serta implementasinya di Indonesia dan single payment system dalam pembayaran PNBP secara online. Penelitian ini menggunakan jenis penelitian normatif dengan pendekatan perundang-undangan. Hasil penelitian menunjukkan bahwa dugaan praktek monopoli yang bertentangan dengan pasal 17 seyogianya dilakukan pemeriksaan oleh KPPU dengan menggunakan pendekatan Rule of reason agar KPPU dapat lebih maksimal melakukan tugasnya mengingat KPPU bukanlah lembaga penegak hukum dan sanksi yang diberikan hanya bersifat administratif. BNI menjadi satu-satunya media bagi para Notaris untuk melakukan pembayaran PNBP dan tidak perlu
} 
bersaing dengan pelaku usaha lain. Pemerintah hendaknya me-review hal ini. Selayaknya tidak hanya terkunci kepada satu model sistem pembayaran elektronik tertentu saja yaitu pada satu kandidat bank yang sudah memenuhi syarat secara teknologi untuk merealisasikan sistem pembayaran online namun juga seharusnya bisa menerima yang non-elektronik.

\section{Pendahuluan}

Indonesia merupakan Negara hukum, sebagaimana dijabarkan dalam pasal 1 ayat 3 Undang-Undang Dasar Negara Republik Indonesia Tahun 1945. Hal ini menjadi fundamental bahwa segala tindakan pemerintah maupun lembaga pemerintahan haruslah berdasarkan aturan hukum dan tindakan-tindakan pemerintah bukanlah merupakan tindakan yang menyimpang dari aturan hukum. Sebagai salah satu negara berkembang yang melaksanakan kegiatan pembangunan, dimana salah satu kegiatan pembangunan yang dilakukan adalah pembangunan nasional. Pembangunan nasional adalah kegiatan yang berlangsung secara terus menerus dan berkesinambungan. Pembangunan tersebut bertujuan untuk mencerdaskan kehidupan bangsa dan untuk menyejahterakan rakyat Indonesia secara adil, makmur dan merata. Demi mencapai tujuan tersebut maka dibutuhkan dana oleh pemerintah.

Keuangan Negara yang baik akan menggambarkan keadaan suatu pemerintahan yang baik pula. Oleh karena itu pemerintah diharapkan agar mampu mengoptimalkan seluruh penerimaan Negara. Secara yuridis melalui norma hukum dasar (state gerund gezet), sistem perekonomian yang diinginkan adalah sistem yang menggunakan prinsip keseimbangan, keselarasan serta memberi kesempatan usaha bersama bagi setiap warga negara sebagaimana diamanatkan dalam Pasal 33 Undang-undang Dasar 1945. ${ }^{1}$ Esensi dari ketentuan dalam pasal 33 tersebut, bahwa perekonomian Indonesia berorientasi pada ekonomi kerakyatan. Hal ini merupakan penuangan yuridis konstitusional dari amanat yang dikandung dalam pembukaan Undang-Undang Dasar Nasional Kesatuan Republik Indonesia Tahun 1945 yang mewujudkan kesejahteraan sosial bagi seluruh rakyat Indonesia. ${ }^{2}$

Pemungutan yang dilakukan suatu negara di samping sebagai sumber penerimaan dalam negeri juga mempunyai peranan fungsi alokasi, fungsi distribusi dan stabilisasi. Sebagaimana yang diketahui bahwa penerimaan negara terbesar berasal dari pajak, namun selain penerimaan pajak ada pula penerimaan yang bukan berasal dari pajak, penerimaan tersebut disebut dengan Penerimaan Negara Bukan Pajak (PNBP). Saat ini pemerintah sedang berupaya untuk meningkatkan penerimaan negara yang bersumber dari Penerimaan Negara Bukan Pajak (PNBP) untuk menyelenggarakan kegiatan pemerintah dan pembangunan nasional.

Guna mengoptimalkan Penerimaan Negara Bukan Pajak (PNBP) guna menunjang pembangunan nasional, maka pemerintah menetapkan suatu undang-undang yang mengatur tentang Penerimaan Negara Bukan Pajak (PNBP) yaitu Undang-Undang Republik Indonesia Nomor 20 Tahun 1997. Undang-undang ini berisi tentang Penerimaan Negara Bukan Pajak (PNBP) sedangkan tentang jenis dan penyetoran Penerimaan Negara

${ }^{1}$ Rokan, M.K. (2012). Hukum Persaingan Usaha Teori dan Praktiknya di Indonesia, Jakarta: Raja Grafindo Persada. Jakarta. h. 12

${ }^{2}$ Chatamarrasjid, C. (2000). Menyikap tabir perseroan (piercing the corporate veil): Kapita selekta hukum perusahaan. Citra Aditya Bakti. Bandung. h. 140-141 
Bukan Pajak (PNBP) diatur dalam Peraturan Pemerintah Republik Indonesia nomor 22 Tahun 1997 sebagaimana perubahan terakhir menjadi Peraturan Pemerintah Republik Indonesia Nomor 52 Tahun 1998 tentang Jenis dan Penyetoran Negara Penerimaan Negara Bukan Pajak, menimbang bahwa perlunya suatu peraturan atas penyetoran Penerimaan Negara Bukan Pajak (PNBP) ke kas negara agar sesuai dengan tujuan Undang-undang Nomor 20 tahun 1997. Selain itu Peraturan Pemerintah ini ditetapkan sebagai langkah penertiban sehingga jenis dan besarnya pungutan yang menjadi sumber penerimaan tersebut tidak menambah beban bagi masyarakat dan pembangunan itu sendiri.

Kelompok penerimaan yang termasuk PNBP terjabar dalam Pasal 2 Undang-Undang Nomor 20 tahun 1997 yakni PNBP dari pengelolaan dana Pemerintah, pemanfaatan SDA, hasil pengelolaan kekayaan negara yang dipisahkan, kegiatan pelayanan yang dilaksanakan oleh Pemerintah, putusan pengadilan dan pengenaan denda administratif, hibah yang merupakan hak pemerintah serta penerimaan lainnya yang diatur dalam Undang-undang tersendiri.

Notaris adalah pejabat umum yang berwenang membuat akta autentik serta memiliki kewenangan lainnya. Selain membuat akta autentik, kewenangan lainnya yang dimiliki Notaris lebih lanjut diatur dalam Pasal 15 Undang-Undang Republik Indonesia Nomor 2 tahun 2014 tentang perubahan atas Undang-Undang Nomor 30 tahun 2004 tentang Jabatan Notaris.3 Kedudukannya sebagai pejabat umum yang membuatkan akta otentik ini secara tidak langsung menempatkan atau menjadikan notaris sebagai salah satu penghubung antara masyarakat yang berkepentingan untuk membayar PNBP kepada Negara. Salah satu contohnya dalam pembuatan akta pendirian PT oleh notaris maka orang yang berkepentingan tersebut diharuskan membayar PNBP kepada Negara yang merupakan salah satu kewajiban yang harus dilakukan oleh orang tersebut agar notaris dapat menyelesaikan aktanya. Kewajiban Penerimaan Negara Bukan Pajak (PNBP) melalui halaman pengumuman Sistem Administrasi Badan Hukum (SABH) ditujukan kepada Notaris, yang memiliki PNBP Pesan Nama Perseroan Tahun 2009 sampai dengan Tahun 2012 dan kewajiban PNBP Pesan Nama Perseroan Tahun 2013 (Hasil Temuan Tahap III BPK) agar segera memenuhi kewajibannya tersebut dan melakukan ${ }^{4}$ verifikasi kepada Direktorat Jenderal Administrasi Hukum Umum. Jika batas waktu tanggal 19 Agustus 2014 tidak melakukan pembayaran maka terhitung tanggal 20 Agustus 2014, akses AHU online akan diblokir, dan Notaris tidak dapat melakukan pengajuan permohonan pengesahan badan hukum dan persetujuan perubahan anggaran dasar serta penyampaian pemberitahuan perubahan anggaran dasar dan perubahan data perseroan terbatas. ${ }^{5}$ Adanya perubahan dalam perihal tata cara pembayaran PNBP melalui notaris ini, sejak tanggal 27 Desember 2017 lalu diumumkan di situs Direktorat Jenderal Administrasi Hukum Umum (Ditjen AHU) mewajibkan notaris melakukan pembayaran PNBP Ditjen AHU dengan rekening Kartu Tanda Anggota Ikatan Notaris Indonesia (INI) yang telah teregistrasi dengan menggunakan aplikasi YAP. Pembayaran yang sebelumnya dengan sistem voucher diubah dengan auto debet di rekening tiap notaris yang terintegrasi dengan KTA INI dan aplikasi YAP. Aplikasi YAP adalah inovasi sistem pembayaran yang dikeluarkan Bank BNI dengan cara pembayaran non tunai menggunakan kecanggihan

\footnotetext{
${ }^{3}$ Arliman, L. (2015). Sumbangsih Werda Notaris Dalam Organisasi Ikatan Notaris Indonesia, Jurnal Yuridika Fakultas Hukum Universitas Airlangga. h. 459

${ }^{4}$ Rotty, D.F. (2016). Pemungutan Penerimaan Negara Bukan Pajak Dalam Keputusan Menteri Hukum dan HAM Republik Indonesia Untuk Badan Hukum Perseroan Terbatas Melalui Media Elektronik. Jurnal Magister Kenotariatan Universitas Brawijaya. h. 19

${ }^{5}$ Ibid.
} 
smartphone. "Aplikasi YAP itu untuk validasi bahwa notaris yang bersangkutan mengizinkan BNI melakukan auto debet terhadap rekeningnya.

Pemilihan Bank BNI sebagai satu-satunya penyedia layanan YAP ini bertentangan dengan Pasal 17 Undang-Undang Nomor 5 Tahun 1999 tentang Larangan Praktik Monopoli dan Persaingan usaha Tidak Sehat (UULPM\&PUTS) sebagaimana dijabarkan: "Pelaku usaha dilarang melakukan penguasaan barang dan/atau jasa yang dapat mengakibatkan terjadinya praktek monopoli dan/atau persaingan usaha tidak sehat".

Selanjutnya, dalam Pasal 17 ayat (2) Undang-undang Nomor 5 Tahun 1999 mengatur lebih lanjut bahwa pelaku usaha patut diduga atau dianggap melakukan penguasaan atas produksi dan/atau pemasaran barang dan/atau jasa sebagaimana dalam ayat (1) apabila:

a. Barang dan/atau jasa yang bersangkutan belum ada substansinya; atau

b. Mengakibatkan pelaku usaha lain tidak dapat masuk ke dalam persaingan usaha barang dan/atau jasa yang sama; atau

c. Satu pelaku usaha atau satu kelompok pelaku usaha menguasai lebih dari 50\% (lima puluh persen) pangsa pasar satu jenis barang atau jasa tertentu.

Sistem pembayaran online dengan sistem YAP ini sebagai layanan auto debet yang diluncurkan oleh Bank BNI, sehingga menempatkan Bank BNI sebagai satu-satunya Bank tertuju untuk pembayaran PNBP kepada Dirjen AHU. Hal ini mengakibatkan pelaku usaha lain yang dalam kasus ini merupakan bank-bank lainnya tidak dapat masuk dalam persaingan usaha jasa yang sama.

Permasalahan yang dikaji difokuskan pada ketentuan yang berkaitan dengan monopoli dan persaingan usaha tidak sehat di Indonesia dan single payment system dalam pembayaran PNBP secara online melalui aplikasi YAP (Your All Payment)

Tujuan dari penulisan jurnal ilmiah ini adalah untuk mengkaji dan menganalisis ketentuan terkait monopoli dan persaingan usaha tidak sehat serta implementasinya di Indonesia dan single payment system dalam pembayaran PNBP secara online.

\section{Metode Penelitian}

Metode penelitian yang digunakan dalam penulisan jurnal ini adalah yuridis normatif dengan pendekatan perundang-undangan. Metode penelitian yuridis normatif adalah penelitian hukum dari perspektif internal dengan objek penelitiannya adalah norma hukum. ${ }^{6}$ Sumber penelitian jurnal ini menggunakan data yang diperoleh dengan cara menelaah bahan hukum primer yaitu peraturan perundang-undangan dan bahan hukum sekunder berupa doktrin atau teori yang diperoleh dari literatur hukum dan penelitian ilmiah. Selanjutnya akan dikaitkan dengan permasalahan yang akan dibahas yaitu tinjauan yuridis dugaan praktik monopoli pada sistem pembayaran online PNBP Notaris.

\section{Hasil dan Pembahasan}

\subsection{Ketentuan terkait monopoli dan persaingan usaha tidak sehat di Indonesia}

Membahas mengenai hukum persaingan yang merupakan salah satu bagian dari hukum ekonomi, tentu tidak akan lepas dari pembahasan dari mengenai Pasal 33 Undang-undang Dasar 1945 yang berfungsi sebagai panduan normatif dalam menyusun kebijakankebijakan ekonomi nasional. Melalui Pasal 33 Undang-undang Dasar 1945 tersirat bahwa 
tujuan pembangunan ekonomi yang hendak dicapai haruslah berdasarkan kepada demokrasi yang bersifat kerakyatan yaitu adanya keadilan sosial bagi seluruh rakyat Indonesia.

Lahirnya Undang-Undang Nomor 5 Tahun 1999 tentang Larangan Praktik Monopoli dan Persaingan Usaha Tidak Sehat ( atau disingkat UULPM \& PUTS) dikarenakan akan kebutuhan aturan hukum yang pasti untuk memberikan kepastian hukum dan jaminan perlindungan yang sama kepada setiap pelaku usaha dalam berusaha, dengan cara mencegah timbulnya praktik ekonomi dan/atau persaingan usaha yang tidak sehat lainnya, Dengan demikian diharapkan dapat mewujudkan dan menciptakan iklim usaha yang kondusif, dimana para pelaku usaha dapat bersaing secara wajar dan sehat. ${ }^{7}$

Persaingan yang sehat dalam ekonomi pasar bebas memberikan 4 (empat) keuntungan. Pertama, persaingan akan memberikan harga yang kompetitif. Kedua, adanya peningkatan kualitas hidup oleh karena inovasi yang terus-menerus. Ketiga, mendorong dan meningkatkan mobilitas masyarakat. Keempat, adanya efisiensi produktif maupun alokatif. Salah satu ancaman dari pelaku usaha tersebut adalah dengan melakukan praktek monopoli. Definisi praktek monopoli diatur dalam pasal 1 angka 2 UU Nomor 5 Tahun 1999 sebagai berikut:

"Praktek Monopoli adalah pemusatan kekuatan ekonomi oleh satu atau lebih pelaku usaha yang mengakibatkan dikuasainya produksi dan atau pemasaran atas barang dan atau jasa tertentu sehingga menimbulkan persaingan usaha tidak sehat dan dapat merugikan kepentingan umum".

Monopoli merupakan kegiatan yang dilarang di Indonesia. Pelarangan tersebut diatur dalam Undang-undang Nomor 5 Tahun 1999 dikategorikan sebagai salah satu kegiatan yang dilarang untuk dilakukan, yang tercermin dalam Pasal 17 ayat (1) yang menyebutkan bahwa:

"Pelaku usaha dilarang melakukan penguasaan barang dan/atau jasa yang dapat mengakibatkan terjadinya praktek monopoli dan/atau persaingan usaha tidak sehat"

Selanjutnya, dalam Pasal 17 ayat (2) Undang-undang Nomor 5 Tahun 1999 mengatur lebih lanjut bahwa pelaku usaha patut diduga atau dianggap melakukan penguasaan atas produksi dan/atau pemasaran barang dan/atau jasa sebagaimana dalam ayat (1) apabila :

a. Barang dan/atau jasa yang bersangkutan belum ada substansinya; atau

b. Mengakibatkan pelaku usaha lain tidak dapat masuk ke dalam persaingan usaha barang dan/atau jasa yang sama; atau

c. Satu pelaku usaha atau satu kelompok pelaku usaha menguasai lebih dari 50\% (lima puluh persen) pangsa pasar satu jenis barang atau jasa tertentu.

Hukum persaingan usaha memiliki tujuan untuk menjaga persaingan antar pelaku usaha serta menjadikan persaingan antar pelaku usaha menjadi sehat. Selain itu hukum persaingan usaha bertujuan untuk mendukung sistem ekonomi pasar yang dianut oleh suatu negara. 8 Di Indonesia, esensi keberadaan UULPM \& PUTS pasti memerlukan pengawasan dalam rangka implementasinya yaitu dengan berdirinya KPPU. KPPU adalah sebuah lembaga yang bersifat independen, dimana dalam menangani, memeriksa dan memutuskan atau melakukan penyelidikan suatu perkara tidak dapat/boleh dipengaruhi oleh pihak manapun baik pihak pemerintah maupun pihak lain yang memiliki vested

7 Rahmadi, U. (2004). Hukum Persaingan Usaha di Indonesia. Pustaka Utama. Jakarta. h. 8

8 Rokan, M.K. Op.Cit, h. 27 
interset ataupun conflict of interest, walaupun dalam pelaksanaan wewenang dan tugasnya bertanggung jawab kepada Presiden.

Terkait penegakan hukum antimonopoli dan juga hal persaingan usaha merupakan kewenangan KPPU, meskipun demikian tidak berarti bahwa tidak ada lembaga lain yang berwenang menangani perkara atau sengketa praktek monopoli dan persaingan usaha. ${ }^{9}$

Pihak-pihak yang dirugikan (konsumen) maupun pihak pelaku usaha yang dirugikan dan bahkan masyarakat atau setiap orang yang mengetahui telah terjadi atau patut diduga telah terjadi segala bentuk pelanggaran terhadap Undang-Undang ini, dapat melaporkan secara tertulis kepada KPPU tentang terjadinya pelanggaran dengan menyatakan identitas pelapor secara resmi. Tatacara penanganan perkara diatur dalam Bab VII mulai dari pasal 38 sampai dengan pasal 46 UULPM dan PUTS

Sebagai suatu lembaga independen, dapat dikatakan bahwa kewenangan yang dimiliki oleh Komisi Pengawas sangat besar yang meliputi juga kewenangan yang dimiliki oleh lembaga peradilan. Kewenangan tersebut meliputi penyidikan, penuntutan, konsultasi, memeriksa, mengadili dan memutuskan perkara/sengketa. Khusus menyangkut penegakan hukum, KPPU dapat bersifat aktif maupun pasif.10Aktif artinya KPPU dapat membuat laporan inisiatif sendiri berdasarkan kajian dan analisa yang dilakukan sendiri oleh KPPU ataupun berdasarkan laporan dari masyarakat. Kedua jenis laporan tersebut memiliki kedudukan yang sama dalam penanganannya. Laporan dari masyarakat dapat berasal masyarakat luas selaku konsumen ataupun dari para pelaku usaha sendiri yang merasa ada persaingan yang tidak sehat diantara mereka, bisa juga berdasarkan info dari media massa baik cetak maupun elektronika.

Dalam Undang-undang Nomor 5 Tahun 1999 diatur mengenai perbuatan apa saja yang dapat dikategorikan sebagai pelanggaran terhadap persaingan usaha beserta dengan sanksinya. Sanksi bagi pelanggaran terhadap perbuatan yang bertentangan dengan ketentuan Undang-Undang tersebut dapat berupa sanksi administratif, sanksi pidana pokok sebagaimana terdapat dalam pasal 48 serta dapat juga diberikan sanksi pidana tam bahan seperti diatur dalam pasal 49. Apabila diteliti lebih jauh ketentuan yang terdapat dalam Undang-Undang ini, ternyata KPPU sebagai lembaga yang paling bertanggungjawab melaksanakan Undang-Undang ini tidak memiliki kewenangan untuk menjatuhkan sanksi pidana. Sanksi pidana menurut undang-undang ini merupakan yuridis peradilan. Komisi hanya mempunyai wewenang sanksi administratif saja. Sampai sejauh ini jelas bahwa pelanggaran yang dilakukan atas UULPM \& PUTS ini bukanlah delik yang bersifat aduan (oleh pihak yang dikorbankan/dirugikan). Sebagai keterangan bagi KPPU, UULPM \& PUTS juga memberikan kewenangan pada KPPU untuk dapat melakukan pemeriksaan langsung terhadap pelaku usaha, apabila ada dugaan terjadi pelanggaran terhadap UULPM \& PUTS ini, walaupun tanpa adanya laporan.

Sebagai perkembangan hukum persaingan, penegakan hukum persaingan tidak hanya terkait hukum perdata, melainkan mengandung juga unsur-unsur pidana dan |administrasi._Hal ini dikarenakan pelanggaran terhadap hukum persaingan akan merugikan masyarakat secara luas dan umum, juga merugikan perekonomian Negara. Oleh karena itu KPPU berdasarkan Undang-Undang Nomor 5 Tahun 1999 sebagai lembaga administratif hanya melakukan pengawasan dan penegakan hukum persaingan serta menjatuhkan sanksi administratif, sedangkan terkait penjatuhan sanksi pidana

\footnotetext{
${ }^{9}$ Ibid. h. 59

${ }^{10}$ Ibid.
} 
maupun perdata KPPU tidak berwenang. ${ }^{11}$ Hukum persaingan usaha yang diatur dalam Undang-Undang Nomor 5 Tahun 1999 substansinya terdiri dari hukum materiil dan juga hukum formil.12

Diperlukan komunikasi dan koordinasi antara KPPU dan PN untuk menyamakan persepsi untuk pelaksanaan eksekusi terhadap putusan KPPU merupakan hal yang sangat penting untuk menegakkan Undang-Undang Nomor 5 Tahun $1999 .{ }^{13} \mathrm{Hal}$ ini menjadi substansial dikarenakan untuk dapat memberikan kepastian hukum kepada para pihak, contohnya pihak Terlapor yang terbukti melakukan kesalahan dan dikenakan sanksi maupun terhadap Pelapor yang merupakan pelaku usaha pesaing atau berkedudukan sebagai pihak ketiga. Selain itu melalui pengaturan yang jelas terkait dengan penegakan hukum dapat memberikan kepastian berusaha dan menciptakan iklim yang kondusif bagi pelaku usaha.

Jadi dapat dilihat dari analisis peran KPPU dalam mengawasi persaingan usaha pada sistem pembayaran Penerimaan Negara Bukan Pajak (PNBP) notaris melalui Aplikasi YAP (Your All Payment menunjukkan bahwa selama kegiatan peran KPPU berjalan berdasarkan peraturan Undang-Undang Nomor 5 Tahun 1999 tentang Larangan Praktek Monopoli dan/atau Persaingan Usaha Tidak Sehat. KPPU berperan dalam melakukan pengawasan dengan berlandasan hukum yaitu tugas yang diatur di Pasal 35 UULPM\&PUTS mengenai penilaian terhadap perjanjian yang dilarang dan kegiatan yang dilarang, penyalahgunaan posisi dominan, bertindak sesuai dengan wewenang KPPU, memberikan saran atau pertimbangan kepada pemerintah terkait praktek monopoli dan/atau persaingan usaha tidak sehat, menyusun pedoman yang berkaitan dengan Undang-Undang Nomor 5 Tahun 1999 tentang Larangan Praktek Monopoli dan/atau Persaingan Usaha Tidak Sehat serta memberikan laporan secara berkala atas hasil kerja KPPU kepada presiden dan Dewan Perwakilan Rakyat.

KPPU dalam menjalankan tugas-tugasnya yang terdapat dalam Pasal 35, KPPU diberi wewenang berdasarkan Pasal 36 UULPM\&PUTS yaitu kewenangan yang dimiliki oleh KPPU sangat luas melainkan mempunyai hak untuk menerima laporan dari masyarakat, melakukan penelitian, penyelidikan, menyimpulkan hasil penyelidikan, memanggil pelaku usaha, memanggil atau menghadirkan saksi atau saksi ahli, hingga menjatuhkan sanksi administratif.

Sejak berdiri sampai 2016, KPPU telah menerima laporan masyarakat terkait dugaan pelanggaran terhadap UU No. 5 Tahun 1999 sebanyak 2.537 laporan dengan rincian sebagai berikut: ${ }^{14}$

Tabel: Laporan Masyarakat Terkait Dugaan Pelanggaran Terhadap UU No. 5 Tahun 1999

\begin{tabular}{ccc}
\hline Tahun Jumlah Laporan & $\begin{array}{c}\text { Kasus yang } \\
\text { ditangani }\end{array}$ \\
\hline
\end{tabular}

\footnotetext{
${ }^{11}$ Mantili, R., Kusmayanti, H., \& Afriana, A. (2016). Problematika Penegakan Hukum Persaingan Usaha di Indonesia dalam Rangka Menciptakan Kepastian Hukum. PJIH. 3(1). h. 128

${ }^{12}$ Ibid. h. 130

${ }^{13}$ Rico, P. (2014). Efektifitas Peran Komisi Pengawas Persaingan Usaha (KPPU) dalam Penanganan Kasus Dugaan Kartel Terkait Praktek Monopoli dan Persaingan Usaha Tidak Sehat, Jurnal Universitas Atmajaya Yogyakarta. h. 12

${ }^{14}$ Ibid.
} 


\begin{tabular}{ccc}
\hline 2000 & 7 & 2 \\
\hline 2001 & 31 & 5 \\
\hline 2002 & 48 & 8 \\
\hline 2003 & 58 & 9 \\
\hline 2004 & 77 & 9 \\
\hline 2005 & 183 & 22 \\
\hline 2006 & 139 & 18 \\
\hline 2007 & 244 & 31 \\
\hline 2008 & 232 & 68 \\
\hline 2009 & 204 & 35 \\
\hline 2010 & 215 & 42 \\
\hline 2011 & 237 & 13 \\
\hline 2012 & 212 & 9 \\
\hline 2013 & 191 & 12 \\
\hline 2014 & 114 & 19 \\
\hline 2015 & 136 & 22 \\
\hline 2016 & 209 & 24 \\
\hline
\end{tabular}

Dikaitkan dengan kasus pada jurnal ini, permasalahan Pemilihan Bank BNI sebagai satusatunya penyedia layanan YAP ini bertentangan dengan Pasal 17 Undang-Undang Nomor 5 Tahun 1999 tentang Larangan Praktik Monopoli dan Persaingan usaha Tidak Sehat. Sistem pembayaran online dengan sistem YAP ini sebagai layanan autodebet yang diluncurkan oleh Bank BNI, sehingga menempatkan Bank BNI sebagai satu-satunya Bank tertuju untuk pembayaran PNBP kepada Dirjen AHU. Hal ini mengakibatkan pelaku usaha lain yang dalam kasus ini merupakan bank-bank lainnya tidak dapat masuk dalam persaingan usaha jasa yang sama. Dugaan praktek monopoli yang bertentangan dengan pasal 17 ini seyognyanya harus dilakukan pemeriksaan oleh KPPU dengan menggunakan pendekatan Rule of reason dimana suatu pendekatan yang digunakan oleh lembaga otoritas persaingan usaha untuk membuat evaluasi mengenai akibat perjanjian atau kegiatan usaha tertentu, guna menentukan apakah suatu perjanjian atau kegiatan tersebut bersifat menghambat atau mendukung persaingan usaha. Dengan melakukan pendekatan tersebut diharapkan didapatkan hasil oleh KPPU apakah kasus ini memenuhi syarat untuk masuk dalam list kasus yang layak untuk ditangani lebih mendalam oleh KPPU. Agar KPPU dapat lebih maksimal dalam melakukan tugasnya ini diperlukan untuk meninjau ulang kewenangan dan tugas yang dibebankan kepada KPPU, mengingat KPPU bukanlah lembaga penegak hukum dan sanksi yang diberikan hanya bersifat administratif. Pengaturan yang ketat dan tegas terkait dengan hukum acara persaingan usaha akan menciptakan keadilan, kepastian hukum dan kemanfaatan bagi Negara Indonesia ini yang pada akhirnya akan meningkatkan perekonomian Negara.

Selain itu juga diperlukannya sinkronisasi dan harmonisasi antara UU Nomor 5 Tahun 1999 dengan undang-undang lainnya termasuk HIR/Rbg yang bersifat lebih general, maupun kebijakan lainnya yang dibuat oleh pemerintah pusat atau daerah di berbagai sektor maupun lintas sektor mengingat banyaknya kebijakan yang dibuat pemerintah berpotensi menimbulkan persaingan usaha tidak sehat. Pada prinsipnya penyempurnaan dari Undang-Undang No. 5 Tahun 1999 sangatlah penting apabila melihat praktek penegakan hukum persaingan usaha di Indonesia yang telah berusia 10 tahun ini. Pemerintah dan Dewan Perwakilan Rakyat (DPR) telah menyepakati Program Legislasi Nasional (Prolegnas) Tahun 2016. Dari sekian jumlah daftar RUU Prolegnas 2017, terdapat revisi Undang-Undang (UU) No. 5 Tahun 1999 tentang Larangan Monopoli dan 
Persaingan Usaha Tidak Sehat. Bagi kalangan pelaku usaha, aturan tersebut menjadi penting., keberadaan revisi UU tersebut masih di tangan Badan Legislasi (Baleg) DPR. Sebab, draft revisi UU tersebut mesti diharmonisasi, sebelum diambil keputusan untuk dijadikan usul insiatif DPR dalam rapat paripurna. Isu krusial lain terkait dengan Pasal 19 ayat (2) dan Pasal 26 ayat (2) sebagaimana tertuang dalam draft revisi UU tersebut. Kedua pasal itu terkait kewenangan pemberian penjatuhan sanksi administratif atas ketentuan hukum yang melanggar larangan praktik monopoli yang diatur dalam peraturan KPPU. Seharusnya, aturan penjatuhan sanksi ini setingkat peraturan pemerintah (PP), bukan lagi peraturan KPPU. 15

\subsection{Single payment system dalam pembayaran PNBP secara online melalui aplikasi YAP (Your All Payment)}

Penggunaan informasi teknologi (IT) di negara-negara berkembang sudah semakin pesat dan memasuki berbagai kebutuhan. Pemerintah semakin menunjukkan kebutuhan yang terus meningkat terhadap pemakaian IT agar bisa menjadikan kerja birokrasi lebih efektif dan efisien dalam melayani kebutuhan masyarakat. Di era digital saat ini arus informasi yang masuk memerlukan kesiapan dan responsivitas sistem informasi yang memadai sehingga bermanfaat dalam pengembangan berbagai bidang yang menjadi tujuan kelembagaan/organisasi. Dalam konteks perkembangan teknologi informasi dan komunikasi secara umum, proyek pengembangan e-government telah menjadi bagian dari kebijakan nasional di seluruh dunia, dan secara global proyek e-government masih terbatas dalam memberikan layanan publik secara digital yang difokuskan pada optimalisasi transaksi, meningkatkan transparansi dan memperluas pelayanan secara online.

Pengembangan e-government adalah untuk memberikan kesempatan kepada masyarakat dan sektor swasta untuk mengakses layanan pemerintah melalui pemberian layanan yang terintegrasi, efektif dan efisien di mana saja, kapan saja dan dalam bentuk yang nyaman melalui penggunaan internet dan saluran lain seperti ponsel, dan lain sebagainya. Undang-Undang Nomor 25 Tahun 2009 tentang Pelayanan Publik mendefinisikan pelayanan publik sebagai berikut:

"Pelayanan publik adalah kegiatan atau rangkaian kegiatan dalam rangka pemenuhan kebutuhan pelayanan sesuai dengan peraturan perundang-undangan bagi setiap warga negara dan penduduk atas barang, jasa, dan/atau pelayanan administratif yang disediakan oleh penyelenggara pelayanan publik."

Konsep pelayanan publik dalam e-government relatif sederhana, tetapi prinsipnya adalah sebelum dielektronikkan, secara manual telah terstandarisasi segala sesuatunya, termasuk keterlibatan pihak ketiga.16 Untuk mendukung dan memfasilitasi pelayanan publik yang mudah, murah, cepat dan transparan sesuai dengan amanat Undang-Undang Nomor 25 Tahun 2009 tentang Pelayanan Publik Kementerian Hukum dan Hak Asasi Manusia telah berinisiatif melakukan pengembangan sistem e-government dan sebuah sistem informasi manajemen untuk mendukung pelaksanaan tugas koordinasi serta pemberian dukungan administrasi di lingkungan Kementerian Hukum dan Hak Asasi Manusia dan membangun pengelolaan dukungan layanan Teknologi Informasi (TI) melalui penyusunan

${ }^{15}$ http://www.hukumonline.com/berita/baca/lt58aac911b652b/isu-krusial-revisi-uu-larangan-praktikmonopoli-dan-persaingan-usaha, diakses pada 10 Juli 2018

${ }^{16}$ Ferdiansyah, V. (2012). Study Fenomenologi Rw-Net Sebagai Pelayanan Publik Yang Transparan Dan Akuntabel Dengan Optimalisasi Fungsi E-Government Di Pemerintah Kota Bandung. Jurnal Ilmu Komunikasi. 1(1) 
Rencana Induk Pengembangan Sistem Informasi Manajemen Kementerian Hukum dan Hak Asasi Manusia (SIMDK) tahun 2005-2010. Pengembangan SIMDK tersebut merupakan kerangka dasar pelaksanaan e-government di lingkungan Kementerian Hukum dan Hak Asasi Manusia.

Kementerian Hukum Dan HAM berupaya untuk memberikan layanan yang cepat, tepat, murah, transparan dan akuntabel dengan memanfaatkan perkembangan teknologi, hal ini dapat dibuktikan dengan masyarakat dapat mengakses layanan publik maupun berinteraksi melalui situs-situs yang ada yaitu: Direktorat Jenderal Imigrasi, Direktorat Jenderal AHU dan Direktorat Jenderal Kekayaan Intelektual dengan mengakses melalui situs: http://www.imigrasi.go.id/; http://www. dgip.go.id/; https://ahu.go.id/.

Kemenkumham melalui Direktorat Jenderal Administrasi Hukum Umum (Ditjen AHU) telah memperkenalkan kepada masyarakat contoh nyata penerapannya beberapa diantaranya yakni: pendaftaran Notaris, Perseroan, Yayasan, pembayaran PNBP melalui notaris yang dilakukan dengan aplikasi YAP (Your All Payment. Jadi dengan system online, masyarakat dapat mengakses dengan mudah, efisien dan efektif, tidak harus datang ke kantor wilayah di masing-masing provinsi atau datang ke kantor Ditjen AHU di Jakarta.

Mengkhusus dalam hal pembayaran PNBP melalui notaris yang dilakukan dengan aplikasi YAP (Your All Payment ini diresmikan dengan Surat Edaran Direktorat Jenderal Administrasi Hukum Umum No. AHU.1.UM.01.01-767 Tahun 2018 tentang Penutupan Layanan Helpdesk Pembayaran PNBP secara Auto debet, yang selanjutnya disebut "Surat Edaran Dirjen AHU". Sejak berlakunya pemberhentian pembayaran PNBP secara auto debet termasuk juga layanan helpdesk pelayanan PNBP pada line telepon tidak dioperasionalkan kembali. Perubahan dalam perihal tata cara pembayaran PNBP melalui notaris ini, sejak tanggal 27 Desember 2017 diumumkan di situs Direktorat Jendral Administrasi Hukum Umum (Ditjen AHU) mewajibkan notaris melakukan pembayaran PNBP Ditjen AHU dengan rekening Kartu Tanda Anggota Ikatan Notaris Indonesia (INI) yang telah teregistrasi dengan menggunakan aplikasi YAP (Your All Payment.

Sistem ini juga bertujuan untuk melakukan pendataan ulang para notaris se-Indonesia. Dengan diwajibkan melakukan pembayaran PNBP lewat auto debet aplikasi YAP, para notaris tak punya pilihan lain kecuali mengurus pembuatan rekening khusus aplikasi YAP. Rekening ini pun dibuat terintegrasi sebagai Kartu Tanda Anggota (KTA) INI.Tercatat di AHU notaris ada 17.000, yang aktif melakukan pembayaran PNBP ada 8000, sekarang yang mengajukan pembuatan rekening untuk aplikasi YAP ada 16.000.17 Sudah menjadi rahasia umum bahwa ada banyak notaris yang sudah tidak lagi aktif menjalankan tugas jabatannya apalagi menghasilkan PNBP bagi kas negara. Hanya saja tidak ada mekanisme hukum yang tersedia saat ini untuk memberhentikan notaris sebagai pejabat umum selain karena alasan pensiun, permintaan sendiri, atau karena melanggar perbuatan yang dilarang UU Jabatan Notaris. Sementara para notaris yang tidak aktif itu tidak diketahui kondisinya dan patut diduga memang tidak mempunyai penghadap sehingga tidak menyumbang pemasukan PNBP. Pungutan PNBP harus didasarkan pada undang-undang dimana harus dibayar oleh masyarakat secara pasti dan tidak mengenal kompromi, hal ini tergolong dalam asas kepastian hukum dalam pemungutan PNBP yakni memuat subjek, objek, besarnya PNBP dan ketentuan mengenai waktu pembayarannya.18

${ }^{17}$ http://wwww.hukumonline.com/berita/baca/lt5a6c3cd551d6b/sistem-pembayaran-online-di-aplikasi-yap, diakses pada tanggal 11 Juli 2018

${ }^{18}$ Kurniasih, D. A. (2016). Pembaharuan Pengelolaan Penerimaan Negara Bukan Pajak. Jurnal Rechts Vinding: Media Pembinaan Hukum Nasional, 5(2), p.228. 
PNBP hanya dipungut oleh pemerintah pusat dan tidak memberikan wewenang kepada pemerintah daerah, baik provinsi maupun kabupaten/kota untuk memungut PNBP. ${ }^{19}$

Pembayaran yang sebelumnya dengan sistem voucher diubah dengan auto debet di rekening tiap notaris yang terintegrasi dengan KTA INI dan aplikasi YAP. Aplikasi YAP adalah inovasi sistem pembayaran yang dikeluarkan Bank BNI dengan cara pembayaran non tunai menggunakan kecanggihan Smartphone. "Aplikasi YAP itu untuk validasi bahwa notaris yang bersangkutan mengizinkan BNI melakukan auto debet terhadap rekeningnya. Pemilihan Bank BNI sebagai satu-satunya penyedia layanan YAP ini bertentangan dengan Pasal 17 Undang-Undang Nomor 5 Tahun 1999 tentang Larangan Praktik Monopoli dan Persaingan usaha Tidak Sehat.

Kebijakan Direktorat Jenderal Administrasi Hukum Umum Kemenkumham tentu menimbulkan dugaan adanya pemberian keistimewaan kepada salah satu pelaku usaha yaitu Bank BNI untuk menjadi perantara payment satu-satunya atas pembayaran PNBP oleh Notaris. Akibatnya tentu BNI menjadi satu-satunya media bagi para Notaris untuk melakukan pembayaran PNBP dan tidak perlu bersaing dengan pelaku usaha lain. Maka pelaku usaha lain kehilangan haknya untuk menawarkan jasa yang sama dengan harga lebih baik bagi konsumen. Selain itu, praktik ini mengakibatkan Notaris tereksploitasi karena konsumen tidak mempunyai pilihan dalam hal pembayaran PNBP karena telah ditentukan hanya melalui YAP lah transaksi tersebut dapat dilakukan. Para Notaris pun mau tidak mau harus mempunyai rekening BNI dan melakukan registrasi sebagai pengguna YAP tersebut.

Sehubungan dengan adanya dugaan praktek-praktek monopoli, terdapat pula suatu anggapan yang menyatakan bahwa hal tersebut dapat menimbulkan dampak yang tidak baik terhadap birokrasi di lingkungan pemerintahan, karena di dalamnya ada tersembunyi korupsi dan penyalahgunaan kekuasaan untuk melindunginya. Pernyataan tersebut mengandung suatu makna, bahwa di balik usaha-usaha praktek monopoli terdapat suatu kerja sama yang tidak dapat "dibuka" antara kelompok bisnis swasta dan birokrat yang memiliki kepentingan-kepentingan ekonomi. ${ }^{20}$ Struktur birokrasi dengan sistem nilai budaya patronase dengan pemahaman aparat pelayanan yang lebih rendah harus loyal kepada pimpinan sebagai pribadi, bukan kepada visi dan misi institusi birokrasi serta tujuan pelayanan kepada publik. ${ }^{21}$

Meskipun sistem pembayaran online ini tentunya berdampak positif dengan memberikan kepastian pelayanan AHU Online tidak berpihak pada kelompok atau golongan tertentu, karena pelayanan menggunakan sistem yang canggih dan berbasis elektronik. Berbeda dengan sebelum online alat, metode, dan sistem yang sederhana sehingga standarisasi pelayanan tidak mengikuti perkembangan zaman dan kebutuhan masyarakat, Dengan beralihnya pelayanan konvensional ke sistem online, masyarakat sudah dimudahkan dalam penyajian informasi layanan AHU dalam bentuk transparansi, sehingga dapat dimengerti dan dipahami serta tidak menyulitkan pengguna jasa hukum. Jadi perbaikan sistem ini sangat menekankan pada prosedur pelayanan ke arah percepatan

${ }^{19}$ Santoso, W. Y., \& Nugroho, A. D. (2012). Pemanfaatan Penerimaan Negara Bukan Pajak di Bidang Kehutanan dalam Melestarikan Fungsi Lingkungan. Mimbar Hukum-Fakultas Hukum Universitas Gadjah Mada, 21(3), p. 560

${ }^{20}$ Anggraini, A. M. (2003). Larangan Praktek Monopoli dan Persaingan Tidak Sehat; Perse Illegal atau Rule of Reason. Sinar Harapan. Jakarta. h. 4

${ }^{21}$ Desiana, A. (2014). Reformasi Birokrasi Pemerintahan Daerah Menuju Good Governance.Jurnal Manajemen Pemerintahan. h. 25-26. 
waktu, yang mana pelayanan ini berorientasi pada kepuasan masyarakat, perbaikan regulasi pelayanan bersifat universal dan tidak ada keberpihakan.

Meskipun terdapat banyak hal positif yang dapat digarap dari pemberlakuan pembayaran secara online juga tidak menutup kemungkinan muncul beberapa dampak negatif juga dibelakangnya. Untuk dapat mengoperasikan pembayaran PNBP secara online ini digunakan aplikasi YAP dimana menempatkan Bank BNI sebagai satu-satunya Bank tertuju untuk pembayaran PNBP kepada Dirjen AHU. Hal ini dilatarbelakangi dengan kesesuaian kebutuhan Ditjen AHU dengan layanan yang ditawarkan serta kesanggupan BNI menyediakan 15.000 rekening dalam tenggat waktu sebulan dan koneksi ke sistem AHU dalam 2 minggu, maka dari itu pilihan kerjasama jatuh kepada BNI. ${ }^{22}$ Hal inilah yang menjadi faktor atau penyebab utama hal ini terjadi adalah karena ketidakmampuan bank-bank lain untuk menyediakan fasilitas pembayaran yang sama, teknologi yang dimiliki oleh bank-bank lain ini belum dapat memenuhi standar untuk dapat mengoperasikan pembayaran PNBP secara online.

Tentu saja seyogyanya pemerintah harus mengkaji ulang hal ini. Pelayanan publik dalam hal pembayaran PNBP yang dilakukan oleh Dirjen AHU selayaknya diterapkan dengan open system dan tidak hanya bertumpu pada aplikasi YAP saja. Agar tidak terjadinya praktek monopoli jasa yang berupa pembayaran PNBP ini pembayaran kepada Dirjen AHU seharusnya tidak hanya terkunci kepada satu model sistem pembayaran elektronik tertentu saja karena untuk saat ini hanya terdapat satu kandidat bank yang sudah dapat memenuhi syarat secara teknologi menopang untuk merealisasikan sistem pembayaran secara online namun juga seharusnya bisa menerima yang konvensional/non-elektronik sehingga daripadanya dapat mencakup bank-bank lainnya yang belum dapat memenuhi fasilitas secara online dapat turut serta untuk ikut berperan masuk dalam jasa pembayaran PNBP. Jadi tidak adanya suatu bank tunggal yang mendominasi pembayaran PNBP tersebut.

Karena belum siapnya bank-bank lain secara fasilitas untuk turut serta mendukung pembayaran PNBP secara online, agar mereka tetap bisa ikut berpatisipasi tentunya pembayaran konvensional/ non elektronik dihidupkan kembali tetapi hal tersebut harus pula diperhitungkan dengan matang-matang. Dilihat dari Segi kemudahan pelayanan, Pelayanan sebelum online dilakukan dengan cara konvensional, sehingga pelayanan terkesan lama dan rentan terhadap tindak pidana korupsi (pungli), orientasi pelayanan masih menggunakan pendekatan birokrasi siput berjalan lamban dan tidak respon terhadap perubahan. Untuk menanggulangi hal-hal tersebut terjadi kembali kinerja sumber daya manusia harus benar-benar diperbaiki dan juga ditingkatkan kualitasnya, sehingga dapat meminimalisir untuk kemungkinan penyewelengan diatas dapat terjadi kembali.

\section{Kesimpulan}

Pengawasan akan Undang-Undang Nomor 5 Tahun 1999 dalam rangka implementasinya dilakukan oleh KPPU yang merupakan sebuah lembaga yang bersifat independen. Dugaan praktek monopoli yang bertentangan dengan pasal 17 ini seyognyanya harus dilakukan pemeriksaan oleh KPPU dengan menggunakan pendekatan Rule of reason. Dengan melakukan pendekatan tersebut diharapkan didapatkan hasil oleh KPPU apakah kasus ini memenuhi syarat untuk masuk dalam list kasus yang layak untuk ditangani lebih mendalam oleh KPPU. Agar KPPU dapat lebih maksimal dalam melakukan tugasnya ini

\footnotetext{
${ }^{22}$ http://www.hukumonline.com/berita/baca/lt5a6c3cd551d6b/sistem-pembayaran-online-di-aplikasi-yap, diakses pada tanggal 11 Juli 2018.
} 
diperlukan untuk meninjau ulang kewenangan dan tugas yang dibebankan kepada KPPU, mengingat KPPU bukanlah lembaga penegak hukum dan sanksi yang diberikan hanya bersifat administratif. Selain itu juga diperlukannya sinkronisasi dan harmonisasi antara UU Nomor 5 Tahun 1999 dengan undang-undang lainnya termasuk HIR/Rbg yang bersifat lebih general, maupun kebijakan lainnya yang dibuat oleh pemerintah pusat atau daerah di berbagai sektor maupun lintas sektor mengingat banyaknya kebijakan yang dibuat pemerintah berpotensi menimbulkan persaingan usaha tidak sehat.

Kebijakan Direktorat Jenderal Administrasi Hukum Umum Kemenkumham tentu menimbulkan dugaan adanya pemberian keistimewaan kepada salah satu pelaku usaha yaitu Bank BNI untuk menjadi perantara payment satu-satunya atas pembayaran PNBP oleh Notaris. Akibatnya tentu BNI menjadi satu-satunya media bagi para Notaris untuk melakukan pembayaran PNBP dan tidak perlu bersaing dengan pelaku usaha lain. Maka pelaku usaha lain kehilangan haknya untuk menawarkan jasa yang sama dengan harga lebih baik bagi konsumen. Seyogyanya pemerintah harus mengkaji ulang hal ini. Selayaknya tidak hanya terkunci kepada satu model sistem pembayaran elektronik tertentu saja karena untuk saat ini hanya terdapat satu kandidat bank yang sudah dapat memenuhi syarat secara teknologi menopang untuk merealisasikan sistem pembayaran secara online namun juga seharusnya bisa menerima yang konvensional/non-elektronik sehingga daripadanya dapat mencakup bank-bank lainnya yang belum dapat memenuhi fasilitas secara online dapat turut serta untuk ikut berperan masuk dalam jasa pembayaran PNBP. Jadi tidak adanya suatu bank tunggal yang mendominasi pembayaran PNBP tersebut.

\section{Ucapan terima Kasih (Acknowledgments)}

Puji dan syukur penulis panjatkan kehadiran Ida Sang Hyang Widhi Wasa/Tuhan Yang Maha Esa, atas segala rahmat dan karuniaNya sehingga penulis dapat menyelesaikan penulisan jurnal yang berjudul "Dugaan Praktek Monopoli Pada Sistem Pembayaran Penerimaan Negara Bukan Pajak (PNBP) Notaris Melalui Aplikasi YAP (Your All Payment". Penulisan jurnal ini dilakukan sebagai satu syarat untuk memperoleh gelar Magister Kenotariatan pada Program Studi Magister Kenotariatan, Fakultas Hukum Universitas Airlangga. Bagi penulis yang terpenting adalah bahwa penulis telah ikut berbuat dan mengambil peran sesuai kemampuan yang ada dan semua ini dilakukan dengan penuh pengabdian serta keikhlasan.

\section{Daftar Pustaka}

$\underline{\text { Buku }}$

Anggraini, A. M. (2003). Larangan Praktek Monopoli dan Persaingan Tidak Sehat; Perse Illegal atau Rule of Reason. Jakarta: Sinar Harapan.

Chatamarrasjid, C. (2000). Menyikap tabir perseroan (piercing the corporate veil): Kapita selekta hukum perusahaan. Bandung: Citra Aditya Bakti.

Kansil, C.S.T. (1989). Pengantar Ilmu Hukum dan Tata Hukum Indonesia. Jakarta: Balai Pustaka.

Marzuki, P. M. (2008). Pengantar Ilmu Hukum. Jakarta: Kencana.

Ubaedillah, A., \& Rozak, A. (2007). Demokrasi, Hak Asasi Manusia, dan Masyarakat Madani. Jakarta: ICCE UIN Syarif Hidayatullah. 
Rokan, M.K. (2012). Hukum Persaingan Usaha Teori dan Praktiknya di Indonesia, Jakarta: Raja Grafindo Persada.

Suswinarno, (2012). Aman dari Risiko dalam Pengadaan Barang/Jasa Pemerintah. Jakarta: Visimedia.

Rahmadi, U. (2004). Hukum Persaingan Usaha Di Indonesia. Jakarta: PT. Gramedia Pustaka

Jurnal

Arliman, L. (2015). Sumbangsih Werda Notaris Dalam Organisasi Ikatan Notaris Indonesia, Jurnal Yuridika Fakultas Hukum Universitas Airlangga. http://dx.doi.org/10.20473/ydk.v30i3.1770

Desiana, A. (2014). Reformasi Birokrasi Pemerintahan Daerah Menuju Good Governance. Jurnal Manajemen Pemerintahan 1(1). 19-47.

Kurniasih, D. A. (2016). Pembaharuan Pengelolaan Penerimaan Negara Bukan Pajak. Jurnal Rechts Vinding: Media Pembinaan Hukum Nasional, 5(2), 213-228.

Mantili, K.H. (2016). Problematika Penegakan Hukum Persaingan Usaha di Indonesia Dalam Rangka Menciptakan Kepastian Hukum. Jurnal Universitas Padjajaran 3(1). 116-132. https://doi.org/10.22304/pjih.v3n1.a7

Rotty, D. F. (2015). Pemungutan Penerimaan Negara Bukan Pajak Dalam Keputusan Menteri Hukum Dan Hak Asasi Manusia Republik Indonesia Untuk Badan Hukum Perseroan Terbatas Melalui Media Elektronik. Kumpulan Jurnal Mahasiswa Fakultas Hukum. 1-24.

Santoso, W. Y., \& Nugroho, A. D. (2012). Pemanfaatan Penerimaan Negara Bukan Pajak di Bidang Kehutanan dalam Melestarikan Fungsi Lingkungan. Mimbar HukumFakultas Hukum Universitas Gadjah Mada, 21(3), 554-574

Ferdiansyah, V., \& Hidayat, D. (2014). E-Government: Study Fenomenologi Rw-Net Sebagai Pelayanan Publik Yang Transparan Dan Akuntabel Dengan Optimalisasi Fungsi E-Government Di Pemerintah Kota Bandung. J-IKA, 1(1), 1-13.

\section{Internet}

|KPPU. http://www.kppu.go.id/id/2018/03/penegakan hukum, accessed 10 Juli 2018

Hukum online.com. (2017, Februari 20)._Isu Krusial Revisi UU Larangan Praktik Monopoli dan Persaingan Usaha. http://www.hukumonline.com/berita/baca/lt58aac911b652b/isukrusial-revisi-uu-larangan-praktik-monopoli-dan-persaingan-usaha, accessed 10 Juli 2018 Hukum online.com. (2018, january 27)._Sistem Pembayaran Online di Aplikasi YAP Dicaci Maki Oknum Notaris, Ini Kata Dirjen AHU. 
http://www.hukumonline.com/berita/baca/lt5a6c3cd551d6b/sistem-pembayaran-online-diaplikasi-yap, accessed 11 Juli 201

\section{Tesis/Desertasi}

Pakpahan, R. A. (2014). Efektivitas Peran Komisi Pengawas Persaingan Usaha (Kppu) Dalam Penanganan Kasus Dugaan Kartel Terkait Praktik Monopoli Dan Persaingan Usaha Tidak Sehat (Master thesis, UAJY).

\section{Peraturan Perundang-Undangan}

Undang-Undang Dasar Negara Republik Indonesia Tahun 1945

Undang-Undang Republik Indonesia Nomor 20 Tahun 1997tentang Penerimaan Negara Bukan Pajak (Lembaran Negara Republik Indonesia Tahun 1997 Nomor 43, Tambahan Lembaran Negara Republik Indonesia Nomor 3687)

Undang-Undang Nomor 5 Tahun 1999 tentang Larangan Praktek Monopoli dan Persaingan Usaha Tidak Sehat (Lembaran Negara Republik Indonesia Tahun 1999 Nomor 33, Tambahan Lembaran Negara Republik Indonesia Nomor 3817)

Undang-Undang Republik Indonesia Nomor 2 tahun 2014 tentang Jabatan Notaris(Lembaran Negara Republik Indonesia Tahun 2014 Nomor 3, Tambahan Lembaran Negara Republik Indonesia Nomor 5491.

Peraturan Pemerintah Republik Indonesia Nomor 52 Tahun 1998 tentang Jenis dan Penyetoran Negara Penerimaan Negara Bukan Pajak(Lembaran Negara Republik Indonesia Tahun 1998 Nomor 22, Tambahan Lembaran Negara Republik Indonesia Nomor 3760) 